\title{
A REPLY TO PROFESSOR CROSSKEY
}

Chardes Farrman $\dagger$

$\mathrm{E}$

VIDENTLY MR. CROSSKEY AND I do not do our sums in the same way. The "attack" upon him consisted of a book review, "The Supreme Court and the Constitutional Limitations on State Governmental Authority" (hereinafter "Review"). In reviewing a book one should act judicially. My judgment on the assigned portion, Part V, was in exact accord with that subsequently pronounced by Professor Goebel:

Let it be said at once that Mr. Crosskey's performance, measured by even the least exacting of scholarly standards, is in the reviewer's opinion without merit. . . Mr. Crosskey . . . coming to his task with a new axe to grind has seemingly forsworn all canons of objectivity to make himself a grindstone to suit his purposes.2

In Part Two of his present article (hereinafter "Article") he takes his exceptions and makes his explanations. The battle rages around Barron v. Baltimore. ${ }^{3} \mathrm{He}$ undertook to show that the decision was "without any warrant at all" and Marshall's opinion "a sham."" I thought he did exactly what he charged Marshall with having done: announced what was incorrect "as if the correctness thereof were clear and certain, beyond the possibility of any doubt." ${ }^{\prime}$ I will comment on a few typical passages in Part Two; failure to mention others implies no concession.

First, Mr. Crosskey's method of constitutional interpretation: "We ask ... what those words would mean. ..." Thus he settles a very large subject, dogmatically, before he begins his first sentence. If he had stuck to his canon, it would perhaps be in order to meet him on that ground. In fact, however, he ranges widely to argue what participants said (insofar as their words can be made to serve his thesis) and much more what they must be presumed to have intended. The controversy, then, does not turn upon canons of construction. It turns upon what are proper methods of scholarly research and exposition.

$\dagger$ Nagel Professor of Constitutional Law, School of Law, Washington University.

I 21 Univ. Chi. L. Rev. 40 (1953).

2 Book Review, 54 Col. L. Rev. 450, 451 (1954).

37 Pet. (U.S.) 242 (1833).

4 Politics and the Constitution 1056, 1081.

5 Politics and the Constitution 1076; Review, p. 77. 
It misconceives to suggest that my criticism went mainly to a single sentence. (Article, pp. 119-20.) To test the validity of his method, a few key points were probed. I quit only when time and space ran out. One does not have to eat all of an apple to judge of its quality.

Let us turn to a few obvious matters. I hope the reader will have the book review before him. See page 120 of the Article, and pages 47-51 and $57-58$ of the Review.

The [New Hampshire] Convention ... in order to... secure the blessings of Liberty.... Do... ratify the said Constitution for the United States of America; [semicolon] and as it is the opinion of this Convention, that certain amendments and alterations... would remove the fears and quiet the apprehensions of many of the good people of this State, and more effectually guard against an undue administration of the federal Government. . . (Italics supplied.)

一then followed a proposed Bill of Rights, sometimes commanding "Congress shall [not]," sometimes speaking in general terms. What would those words mean? Clearly, the sentence expresses two distinct thoughts: (1) To secure the blessings of liberty, the Constitution is ratified. (2) To guard against an undue administration of the federal government, a bill of rights is proposed. Mr. Crosskey, in his zeal, reads the sentence thus: they sought the blessings of liberty; it would (in his view) better secure those blessings if a bill of rights were imposed upon the states too; so "I see no reason why this proposal of New Hampshire should not be understood to mean what it literally said." Let the reader judge.

Further, Mr. Crosskey states,

I still fail to see why, even [if the New Hampshire and Massachusetts declarations were as Mr. Fairman represented], my omission to mention these declarations would have been reprehensible.... I was seeking to show that demand for limitations on the states was not absent from the situation. For that purpose, one state convention [Virginia] seemed enough. ... (Pp. 121-22.)

Here were two state conventions, whose purpose ( $I$ insist) was clearly to seek a bill of rights limiting only the general government: to attain that objective, sometimes they wrote "Congress shall [not]," sometimes they forbade generally. Eight participants went from those conventions to the First Congress, where the Bill of Rights was framed-eight members to whom the words did not mean what Mr. Crosskey says they mean. Yet Mr. Crosskey sees no lack of candor in omitting to mention these matters; he was seeking only to show that demand for limitations was not absent from the situation. I do not challenge Mr. Crosskey's sincerity; this prepossessed obtuseness to the elementary requirements of scholarly candor is the most significant feature of his entire work. 
Now consider Mr. Crosskey's explanation (pp. 123-24) of his failure to refer to Chancellor Walworth's conclusions, contrary to his own. (Review, pp. 45-46, 69-70.) What it comes to is that Walworth read what Mr. Crosskey read-yes, Walworth refers to the action of the Senateand saw nothing significant in the circumstances that Mr. Crosskey would have us believe were important. So, he explains, there was obviously nothing in what Walworth had to say; and so there was no reason even to mention it. Perhaps the reader, if advised, would have thought otherwise.

A glance at a point, so obvious that one feels mean to have to make a contest: Spencer, C. J., in People v. Goodwin. (Review, p. 70; Article, pp. 125-26.) It was not material, said the judge, to decide whether the Fifth Amendment applied to state courts; "I am ... inclined to the opinion" that it does. (Throughout the discussion of the case, the Chief often said "I.")

Upon the whole, I am of opinion, that... [and here he stated the holding]....

In this opinion my brethren entirely concur. ... ${ }^{6}$

In expressing an inclination on a matter not material, a judge assumes far less responsibility than when he states a firm conclusion. I added that it was "not warranted" to say that [all] "the judges of the Supreme Court of New York ... were of the opinion" that the federal Bill of Rights governed the states. One cannot say whether they concurred in the "inclination." This is simply one of a myriad of instances where Mr. Crosskey takes a penny point and seeks to pass it off for a gold sovereign.

Then there is the much more substantial matter of Spencer's subsequent conduct in the New York constitutional convention of 1821. See the Review, pp. 65-70, where it is made clear that the Chief Justice did not regard the federal Bill of Rights as binding upon New York. Mr. Crosskey seeks to explain away one of the Chief's remarks by providing a new meaning for the "cruel or unusual punishments" provision of the Eighth Amendment; he is happy to explain that doubtless Spencer understood it to mean only that Congress shall not attach any punishment that it regards as cruel or unusual, and that no state legislature shall attach any punishment that it regards as cruel or unusual. With that brilliant bit of exegesis, Mr. Crosskey drops the subject of Spencer and the New York convention.

Bank of Columbia v. Okely, ${ }^{7}$ discussed in the Review at p. 75 and in the

618 Johns. (N.Y.) 187, 201, 207 (1820).

74 Wheat. (U.S.) 235, 242, 244 (1819). 
Article at pp. $127 \mathrm{ff}$. Look away for a moment from Justice Johnson's sentence: does not Mr. Crosskey's entire theory of the case seem improbable? The Court reached out to make a momentous ruling that was unnecessary and indeed out of the rational order for deciding the case-and then secreted it so well that only Mr. Crosskey's industry discovered it. So it is "presumed that the whole Court membership, in 1819, were of opinion" that the Bill of Rights did bind the states. So when in 1833 the Court ruled otherwise, the Justices, it is said, were really taking fright and reversing themselves. (So far as appears, the Okely case was not cited for the holding Mr. Crosskey sees when the question came to be argued in 1833.) A few pages later the reader is invited to "recall" as a fact that the Court, and in particular Justice Story, held the Seventh Amendment to be applicable to the states.

State decisions, prior to Barron v. Baltimore, holding that the federal Bill of Rights did not apply to the states-the Review at 73-74, and the Article at pp. 131-32: Admittedly Mr. Crosskey omitted to mention them, and now he "[does] not see why" this was any dereliction on his part. $\mathrm{He}$ writes:

I was under [no] duty to pursue a subject in which I had no interest. . . After all, state decisions favorable to state power under the Constitution from the early years are not very persuasive evidence. ... (Italics supplied.)

Maybe his readers would have been interested even if he was not; maybe they would have regarded such decisions as relevant and even significant. At any rate, if he was going to exclude all state decisions not favorable to the view he supports, he might in candor have posted a notice such as this:

The author will not cite state decisions unless they are on the side favorable to federal authority.

Is this an admission that throughout his two volumes he has practiced such omission?

Now a glance at those Massachusetts decisions on whether a jury, hopelessly disagreed, may be discharged without the assent of the accused (the Review at pp. 62-64; the Article at pp. $132 \mathrm{ff}$.): The common law concerning double jeopardy provides the answer. The federal Constitution, within the scope of its operation, also forbade double jeopardy. Yet in finding the common law's answer, the state judges, in Mr. Crosskey's view, looked up and made an obeisance to the Fifth Amendment-and then went ahead to do exactly as they would have done even if the Fifth Amendment had not existed. On what does he base his contention that they acknowledged that that amendment was controlling? (It would be 
helpful if the reader would at this point look at 2 Pickering 521, to form his independent judgment.) One Purchase had been convicted of manslaughter by a second jury; the first jury had been dismissed after failure to agree. $\mathrm{He}$ moved in arrest of judgment, contending that his life had been twice put in jeopardy. Counsel's argument is summarized, concluding "[h]e cited the 5th art. of Amendments to the Const. U. S." Then

Davis, Solicitor General, for the commonwealth, cited and relied on Commonwealth v. Bowden, 9 Mass. R. 494; United States v. Coolidge, 2 Gallison, 364 [where the federal circuit court, per Story, J., had sustained the power of the court to discharge the jury, without any reference to the Fifth Amendment]....

From this Mr. Crosskey states boldly that counsel were agreed "the Fifth Amendment was applicable"--because a seven-line summary of the Solicitor General's citations includes no statement that he repelled the point, in a controversy where the common law would in any event be decisive. Chief Justice Parker stated the question as set out in my Review at p. 64 and by Mr. Crosskey at p. 134-and proceeded to discuss the common law without mention of the amendment. On this gossamer thread Mr. Crosskey hangs his conclusion that the court was "explicit that it was deciding the case under the Constitution of the United States." (So in his view this was a ruling adverse to a claim of federal right. It would follow that Purchase could have gone up to the Supreme Courtbut evidently he did not do so.)

From here Mr. Crosskey throws out another gossamer line. Sitting with Parker, C. J., were Justices Wilde and Putnam. (The reader should keep his eye on Parker and Wilde in the discussion that follows.) In my Review (at pp. 58 et seq.) I pointed out that two representatives from Massachusetts in the First Congress-hence, participants in the submission of the Bill of Rights-thereafter sat on the Supreme Judicial Court: Sedgwick (1746-1813; Justice 1802-1813) and Thacher (17541824; Justice 1800-1824). I pointed out that Justices Parker, Wilde, and Jackson sat on the bench with these two founding fathers of the Bill of Rights; further, that Parker, Wilde, and Jackson were members of the Massachusetts Constitutional Convention of 1820 -where the debates, I believe, show clearly that it was understood that the federal Bill of Rights did not bind the states. I said that if the members of the First Congress had designed the Bill of Rights to operate upon the states, then surely Sedgwick and Thacher would have imparted their understanding to their associates in the course of administering justice. (This was not on the basis of any remote conjecture that they would have chatted about it, but because it must have come up in reasoning upon cases before the court.) 
Now (at p. 135) Mr. Crosskey says, in effect: since he has now shown that Parker and Wilde, in Commonwealth v. Purchase, "distinctly recognized" that the Bill of Rights did govern the states, this demonstrates "the unreliability of a great mass of other so-called 'evidence' that Mr. Fairman threw at my head last year. . . . Mr. Fairman's procedure was to follow various prominent Americans of the late eighteenth century, and early nineteenth century, into various state constitutional conventions and state legislatures, and to present their behavior there as 'evidence' that they did not think Amendments II-VIII bound the states." I urge the reader to go back to the Review, at pp. 47-50 (New Hampshire's record); 52-54 (Pennsylvania); 54-56 (Connecticut); 57-64 (Massachusetts); 64-65 (Maine); 65-69 (New York); and 72-73 (Vermont)and then consider whether all this evidence is really demonstrated to be unreliable because Parker, C. J., in the Purchase case, stated that the question to be discussed by the court was "whether by the common law, or by virtue of the constitution of the United States," the second trial was prohibited.

In those passages in the Review one will find numerous instances where men who had been in a position to know if the Bill of Rights had been intended to govern the states were in situations where it would have been their public duty to declare any such knowledge. Mr. Crosskey dismisses the lot by saying that we do not know whether they were "acutely aware of all the detailed provisions" of the Bill of Rights. "II]t must be assumed that the delegates were experts on Amendments II-VIII, in order to provide any basis at all for Mr. Fairman's inferences." ( $P$. 136.) Let the reader examine the Review and consider whether those participants - often state judges-could not qualify as experts on the meaning of a trial jury, indictment by grand jury, and the like. Is it even to be supposed that John Adams-who had won acquittal for a British captain for his part in the "Boston Massacre"-would be so hazy as to have forgotten the provisions of the Bill of Rights? Consider, in contrast, how much weight Mr. Crosskey attaches to the opinions of the law writers, William Rawle, Jr., and Joseph K. Angell. And, looking ahead for a moment, consider how remarkably knowledgeable are Mr. Crosskey's Fourteenth Amendment witnesses; they are so perceptive that they all know just what (Mr. Crosskey says) Bingham meant in a speech in 1859, even better than Bingham himself was able to express it.

What was demonstrated in my discussion of state constitution-making, legislation, and judicial decision was that, in practice, the country never ran on the theory Mr. Crosskey now advocates: never ran that way even when the makers of the Bill of Rights were all about to cry aloud if the 
Constitution was being breached. This is a great bed-rock fact-and no amount of finicking contention about an occasional obscure sentence is going to budge it. Time after time, state conventions deliberated on the theory that they were not restrained by the federal Bill of Rights; sometimes they adopted a provision that would be inconsistent with a federal provision. (By the way, I never assumed that they should know Supreme Court decisions before they were made; I did say that they would have stopped to consider a potential constitutional question.) Mr. Crosskey says (p. 139) that two states in 1790 put into their constitutions certain of the prohibitions of Article I, Section 10, and left others out; therefore, he concludes, it is "not reliable" to attach significance to the fact that states adopted measures which (if the federal Bill of Rights governed) would have been unconstitutional. Now it is easy to understand that a state may duplicate some and not all of the federal restrictions; but this does not lessen the significance of a state provision actually in conflict with what the federal Bill of Rights (if applicable) would command.

One may test Mr. Crosskey's logic by another passage-(Article, pp. 138-39):

(1) William Rawle, Jr., believed that the Bill of Rights limited the states.

(2) Story cited Rawle--not on this point-with approval.

(3) Story wrote that it had been held in the state courts that the "cruel or unusual punishments" clause of the Eighth Amendment did not apply to the states; the point did not seem to have arisen in the federal courts.

So (4) it is to be inferred "from such evidence as we have" that "he agreed with William Rawle, or, at the very least, that he considered the question ... open."

Doubtless this "evidence" is the Okely case, already discussed, where it was "presumed" that in 1819 Story believed what Mr. Crosskey wants him to believe. Here I subscribe to Professor Ernest J. Brown's comment in his book review:

Mr. Crosskey apparently believes that like Antaeus retouching Mother Earth, a conclusion gains strength each time it is repeated. ${ }^{8}$

Now I turn to Part One of Mr. Crosskey's article dealing with my article on the Fourteenth Amendment-2 Stanford L. Rev. 5 (1949) (hereinafter, "Stanford article"). I hope the reader has had that study before him, in order to make a fair judgment on the matters in controversy.

${ }^{8} 67$ Harv. L. Rev. 1439, 1452 (1954). 
The question involved was the validity of the contention of $\mathrm{Mr}$. Justice Black, dissenting in Adamson v. California, ${ }^{9}$ that the history of the adoption of the Fourteenth Amendment showed a purpose to make the Bill of Rights applicable to the states. Going over the same and much additional ground, I reached the conclusion that it did not. I analyzed the fundamental problem, in a federal form of government, of creating individual rights against the state-which I believe is difficult and elusive. I then examined the long history of the debates in 1866, to inquire, very critically, whether the participants really meant to incorporate the Bill of Rights in the new amendment. I thought the comments of the members on what they thought the amendment would do showed that, for the most part, they had failed to think to the bottom of their difficult problem. I said that "[w]hen the Slaughter-House Cases" put the privileges and immunities clause to a rigorous scrutiny, its looseness became apparent." (P. 139.) Mr. Crosskey thinks I was unjustly making "ninnies" (Article, p. 74) out of many of the participants. I find it much easier to believe that a number of members of that Congress were "ninnies" about the difficult problem before them than to suppose that most of the Justices of the Supreme Court have been knaves-which seems to be the conclusion of Mr. Crosskey's book.

Urging the reader to look for himself to my Stanford article and to the Congressional Globe, I here confine myself to a few general observations.

First, I draw attention to the freedom Mr. Crosskey allows himself in handling the material. $\mathrm{He}$ cheerfully goes along with rewriting Article IV, Section 2-although he concedes the result is "not quite" what the text says. (Article, p. 12.) He changes the punctuation (p. 64), adds words (p. 37), obliterates words as "mere rhetoric" (p. 65), amends to help out a speaker who "had [been] somehow confused" (p. 58), charges the reporters with "some slight garbling" (p. 58), assumes that they have made "mistakes and omissions" (p. 37), excuses Bingham or the reporter for "a mistake" and cures it by adding a word that alters the meaning (p. 37), and reminds us that "speakers, especially ardent men like John A. Bingham, are sometimes guilty of slips and lapses" (p. 37). He even supplies Mr. Bingham with a bit of stage property at a moment when it was badly needed. In the Stanford article I had pointed out that Mr. Bingham's reference to "this immortal bill of rights" and the like, when read in context, left the greatest doubt whether he meant specifically the first eight amendments. (Pp. 26, 31, 34.)

9332 U.S. 46, 68 at 71 (1947).

1016 Wall. (U.S.) 36 (1873). 
Mr. Crosskey explains it this way:

Bingham ... had been reading provisions out of the Constitution; he probably had a copy of the document in his hand; and when he came to the place where he referred to "this immortal bill of rights embodied in the Constitution," he may very well simply have held the document up, as Mr. Fairman says, "in [a] spacious gesture." (P. 28.)

You're fudging, Professor Crosskey! You don't know that Bingham had been reading from the Constitution. Did so intelligent a man have to keep the Constitution with him in order to quote its phrases? How can you say that "he probably had a copy of the document in his hand" and waved it when he said "bill of rights"? There we have a practical construction of Mr. Crosskey's idea of what "probably" happened. And what was "probable" tends soon to make the king-row and, on being crowned an absolute certainty, can then be used to bump off opposing facts.

I take time for one comment on one speech in the debates-that of Representative Price, which went without mention in the Stanford article. Hiram Price was an Iowa merchant and banker. Mr. Crosskey quotes, in part, from his speech, and finds it clear that Price thought the proposed amendment would impose the Bill of Rights. (Pp. 33-34.) In the speechalong with much bantering of the Democrats-Price made this direct statement of what he thought the measure meant:

I say, sir, that the intention of the resolution before the House is to give the same rights, privileges, and protection to the citizens of one State going into another that a citizen of that State would have who had lived there for years. ${ }^{11}$

He had passed the time of life, he said, when he expected to travel in the southern country, but he wanted to have a constitution that would protect his children and his children's children who might have occasion to travel in any part of the United States. He showed no concern for protecting the citizen of Iowa at home; his concern was to protect the citizen going into another state.

If nothing of real moment were involved in all this, one would gladly avoid irritating Mr. Crosskey, as Polonius humored Hamlet: the cloud is indeed like a camel . . . backed like a weasel . . a and very like a whale. But this is a constitution we are expounding.

From here on I must hit only the high spots. The application of the Bill of Rights to the states means, inter alia, that no person shall be held to answer for a capital or otherwise infamous crime unless on a presentment or indictment of a grand jury; that in all criminal prosecutions the

1 Cong. Globe, 39th Cong. 1st Sess. 1066 (1865-66). 
accused shall enjoy the right to trial by a common-law jury of twelve; and that in suits at common law, where the value in controversy exceeds twenty dollars, there is a right of trial by jury. General talk about making the Bill of Rights applicable to the states has an obscure and beguiling sound if one fails to pin it firmly to those specific provisions.

At the outset, Mr. Crosskey simply announces that the privileges and immunities clause of the Fourteenth Amendment has this "undeniably obvious" meaning and purpose: to impose the Bill of Rights upon the states. "The clause seems about as clear as a clause could be." (P. 6.)

That is a great big dogmatic assumption.

How do we know that that was the meaning and purpose? Because in $1859 \mathrm{Mr}$. Bingham made a speech in Congress. Let us take Mr. Crosskey's account at pp. 13-14. Bingham talked about natural rights, and did not mention the civil jury, etc.-but let's not quibble.

Next, another assumption: Bingham's views were "the common faith of the political party" to which he belonged. (P.11.) So every Republican in 1866-however confused he may appear in the debate-really meant that he wanted what Mr. Crosskey says Bingham meant in 1859. Mr. Crosskey says that this was a "peculiar view" that all the Republicans shared. (P. 16.) They "held ideas distinctly their own. ..." (P. 18.) If we will only accept and keep constantly in mind these "old, forgotten Republican constitutional ideas" (p. 21) - then all the unproved assumptions that went into the premise will come out in the conclusion.

I interject a few words about my treatment of Mr. Bingham. Mr. Crosskey thinks I question his truthfulness. (P. 14.) No, I was clear in saying (Stanford article, p. 137):

We have dealt with Mr. Bingham in this article on the view that, however confused, he was sincere. If for a moment one were to suppose that he was astutely endeavoring to bring a wooden horse into the Constitution, certainly the result must be clear: no such fraud on the nation could be countenanced.

Mr. Crosskey says that Bingham drafted on the theory that his own very special ideas, and not the Supreme Court's decisions, were the standing law (p. 25). I would think it plain that anyone who acted on such a view was a purblind and bull-headed draftsman. But Mr. Crosskey finds him a kindred spirit and pronounces the amendment to have been "painstakingly and skilfully drawn."

And the Democrats in Congress-were they aware that the Republicans were drafting and debating a constitutional amendment in a peculiar

12 Politics and the Constitution 1084. 
language of special meaning? Yes, Mr. Crosskey assures us, the Democrats "very certainly understood." (P. 35.)

So in Mr. Crosskey's theory the Fourteenth Amendment-by far the most important amendment to the Constitution-was framed and discussed under very special conditions. The movers acted on the assumption that their own peculiar ideas, and not the decisions of the Supreme Court, were the law. Time passed, and this special vocabulary was forgotten-and then Professor Crosskey discovered the Rosetta stone and deciphered the ancient records.

One of the many objections to this theory is suggested by Professor Hart's comment upon another part of Mr. Crosskey's book:

The readiness ... to impute lack of scruple to others, wholesale, is worthy of note. But what is of main interest is the ineffability of the assumption that in the interpretation of a document embodying a grant of fundamental powers from the people to their government the representations made to the people to obtain the grant are irrelevant, and what alone counts are the secret thoughts of the men who drew the document the people approved..$^{13}$

With slight paraphrase, the same comment may be made on his theory of the Fourteenth Amendment. Personal notions floating about may be of interest in a history of political ideas, but they cannot be admitted as operative facts in the making of a constitution.

If the Fourteenth Amendment was as clearly drawn as Mr. Crosskey believes, and meant what he says it meant, surely that plain meaning would have come out, time and time again, in the ratifying legislatures. I traced all the records that are available. (Stanford article, pp. 81-132.) Governor after governor, submitting the proposed amendment, commented on its purpose, but never was it suggested that the federal Bill of Rights would now govern the state. The governor of Ohio made a vague reference to protecting freedom of speech and other essentials of free government. In Massachusetts a committee, zealous for Negro rights, complained that the amendment merely duplicated the Bill of Rights; they urged deferment. The minority report, recommending ratification, was adopted. I think the barrenness of these records exceedingly significant; Mr. Crosskey counts the silences as neutral.

If the proposed Fourteenth Amendment had been understood to impose the Bill of Rights, surely the legislatures of states whose constitution or laws would be struck down would have so noted, and stopped to consider, before voting to ratify. I found many such inconsistencies-with no suggestion that the adoption of the proposed amendment would react

${ }^{13}$ Book Review, 67 Harv. L. Rev. 1456, 1481 (1954). 
upon these state institutions. Mr. Crosskey brushes this practical aspect aside: "unless a legislator were an expert on the Bill of Rights" he might never have been aware of a conflict with the local law. (P. 112.) Can one believe that a legislature would not have many members who knew the local provisions on jury and grand jury, and who would cry out if it had been supposed that the amendment would affect the local legislation?

If the proposed amendment had been understood by the Democrats to mean that the Bill of Rights would govern the states-and we are assured that the Democrats understood the peculiar idiom of the Republicanswould they not have made political capital out of the menace such a proposal held? Was it perhaps that Reconstruction was such an Era of Good Feeling that the Democrats forbore to denounce throughout the North what the Republicans were doing?

Consider what it would have meant to impose the grand jury, the common-law jury of twelve, and the civil jury where the ad damnum exceeds twenty dollars. I traced all that, in the Stanford article. There are, of course, no petty cases in the federal courts upon which the Seventh Amendment can work; but it would have been very different in the state courts.

Mr. Crosskey has to meet these points about juries, and he says two interesting things.

(1) The federal provisions on grand jury and criminal jury are exactly what the overwhelming majority of Americans would want; they ought to be imposed.

(2) The civil jury is "an atrocious waste of manpower"; the Seventh Amendment is a "thoroughly bad provision." (Pp. 115-16.)

But the consideration that the Fourteenth Amendment (as Mr. Crosskey reads it) would have imposed this atrocity upon unwilling states-and that any such imposition, if understood, would have been vehemently resisted-all this, Mr. Crosskey insists, has nothing to do with the case. (P. 116.)

If the Fourteenth Amendment did impose the Bill of Rights upon the states, then men went to the penitentiary, or to their death, under procedures which violated the Constitution. As I pointed out in the Stanford article, if the lawyers of the country had had an inkling that that was what the amendment meant, they would have demanded for their clients the federal rights thus secured. The reports would be full of the cases. Mr. Crosskey says merely that

These phenomena do, indeed, tend to suggest that there may have been considerable inattention to the amendment at the time of its adoption and, consequently, some 
unawareness of the true tenor of its various provisions. This sort of thing is always true. (P. 119.)

"Considerable inattention" to the great amendment that was to settle the differences within a nation so recently at war! "This sort of thing is always true." (With Prohibition, Repeal, Woman Suffrage, etc., didn't the word get around?) The amendment, so "crystal clear," met with "considerable inattention," even by lawyers in states whose criminal procedure was, in Mr. Crosskey's view, now invalidated!

Further, in the Stanford article I pointed out that even the 39th Congress, which framed the amendment, when it came to passing upon the new constitutions for the reconstructed states, seemed pretty clearly to consider that the provisions of the Bill of Rights did not have to be complied with. (Pp. 126-32.)

Toward the end of the Stanford article I wrote, "If the theory that the new privileges and immunities clause incorporated Amendments I to VIII found no recognition in the practice of Congress, or in the action of the state legislatures, constitutional conventions, or courts, it is not surprising that the contemporary Supreme Court knew nothing of it either" (p. 132) -citing Twitchell v. Pennsylvania. ${ }^{14}$ For once, Mr. Crosskey and I agree upon a case. He writes:

The cases Mr. Fairman cited were cases in which counsel and courts should have given heed to the fact, but did not, that the Fourteenth Amendment had made the Bill of Rights good against the states. Instead, the Fourteenth Amendment was totally ignored: nothing at all was said about it. These cases, which include one in the Supreme Court of the United States, in 1869, undoubtedly indicate that there were some people in the country ... who were unaware of the true tenor of the new amendment. The case in the Supreme Court indicates that the Justices of the Court were among this number: a rather shocking, but by no means unique, indication of the inalertness of the men who composed the Court of the period. (P. 113.)

In the later years, the old, original, peculiar ideas that gave meaning to the amendment were forgotten. In the years of its youth, the amendment's true meaning was ignored; people-even Justices-were unaware of its "true tenor." There, I believe, we have the gist of the thing: Mr. Crosskey's Fourteenth Amendment is an amendment that never was.

147 Wall. (U.S.) 321 (1869). 